\title{
DIFFUSE LARGE B CELL LYMPHOMA PRESENTED WITH MASSIVE THYROID GLAND ENLARGEMENT AND RESEMBLING THYROID CANCER
}

\section{MASIF TİROİD BEZİ BÜYÜMESİ İLE PRESENTE OLAN VE TİROİD KANSERİII ANDIRAN DİFFÜZ BÜYÜK B HÜCRELİ LENFOMA}

Nebiye YAPICI ${ }^{1}$, Fatih KARAAHMET ${ }^{2}$, Murat KEKILLLI ${ }^{3}$

\begin{abstract}
Diffuse large B cell lymphoma (DLBCL) is the most common nonHodgkin lymphoma in adults. It accounts for about $30-58 \%$ of all Non-Hodgkin lymphomas. The disease often presents as a rapidly growing nodal or extranodal mass with systemic symptoms. It can be presented with a life-threatening emergency such as a sudden neck swelling. We aimed to present a case of neck swelling that was presented at the age of 81 with sudden neck swelling and dyspnea, to whom an urgent tracheostomy was performed.
\end{abstract}

Keywords: Diffuse Large B Cell Lymphoma, Thyroid Gland, Massive Enlargement

\section{ÖZET}

Diffüz büyük B hücreli lenfoma (DLBCL), Non-Hodgkin lenfomalar arasında erişkinlerde en sık görülen lenfomadır. Tüm Non-Hodgkin lenfomaların yaklasık \% 30-58'ini olusturur. Hastalık çoğunlukla sistemik semptomlarla birlikte, hızlı büyüyen nodal veya ekstranodal kitle șeklinde ortaya çıkar. Ani boyun şişliği gibi hayati tehlike oluşturabilecek acil bir durum ile karşımıza gelebilir. Biz 81 yaşında ani boyun şişliği ve dispne ile başvuran, acilen trakeostomi açılan bir boyun şişliği vakasını sunmayı amaçladık.

Anahtar kelimeler: Diffüz büyük B hücreli lenfoma, tiroid bezi, masif büyüme

${ }^{1}$ Department of Internal Medicine Ankara Training and Research Hospital, Ankara, Turkey

${ }^{2}$ Department of Internal Medicine, Division of Gastroenterology, Private Medicana International Ankara Hospital, Ankara, Turkey ${ }^{3}$ Department of Internal Medicine, Division of Gastroenterology, Gazi University, Faculty of Medicine, Ankara, Turkey

Geliș Tarihi / Submitted : Aralık 2019 / December 2019

\section{Sorumlu Yazar / Corresponding Author:}

Nebiye Yapic1

Department of Internal Medicine Ankara Training and Research Hospital, Ankara,Turkey

Gsm: +905313828218

Kabul Tarihi / Accepted : Aralık 2020 / December 2020

Yazar Bilgileri /Author Information:

Nebiye YAPICI (ORCID: 0000-0002-3544-1194),

Fatih KARAAHMET (ORCID: 0000-0002-9846-5804),

Murat KEKILLII (ORCID: 0000-0002-3063-8748) 


\section{INTRODUCTION}

Thyroid cancer is the fifth most common cancer in women around the world, and an estimated over 62000 new cases occurred in men and women in 2015. Differentiated thyroid cancer is the most frequent subtype of thyroid cancer. Other -rare subtypes of thyroid cancer- patients present with medullary, anaplastic cancers and lymphoma (1).

The neoplastic causes of massive neck swelling and life threatening condition are associated with anaplastic thyroid cancers and diffuse large B cell lymphoma (DLBCL). DLBCL is the most common form of NHL, accounting for 22 percent of all B cell lymphomas. Although slightly more common in men than women, DLBCL occurs in both men and women. Its incidence usually increases with age and about half of the patients are over 60 years of age. DLBCL is an aggressive lymphoma that can occur in lymph nodes or outside the lymphatic system (gastrointestinal system, testes, thyroid, skin, breast, bone or brain) (2). We aimed to present an 81-year-old patient with a rapidly expanding thyroid gland and neck swelling related to DLBCL.

\section{CASE PRESENTATION}

An 81 years-old woman presented with three months history of dyspnea, neck swelling and rapidly enlarging thyroid gland. The patient has a history of hypothyroidism and she was under levothyroxine replacement treatment. On physical examination, she was afebrile, with a blood pressure of 133/66 $\mathrm{mmHg}$, and a pulse of 92 beats per minute. The thyroid gland was visible on inspection. Complete Blood Count showed a white-cell count of $10.810 / \mathrm{mm} 3$, the hemoglobin level was $12.7 \mathrm{~g} / \mathrm{dl}$, creatinine was $0.79 \mathrm{mg} / \mathrm{dl}$, LDH was $274 \mathrm{IU} / \mathrm{L}$, TSH was $0.13 \mathrm{mIU} / \mathrm{L}$, fT4 was $1.88 \mathrm{ng} / \mathrm{dl}$, fT3 was $3.57 \mathrm{ng} / \mathrm{dl}$ and anti-TPO was $46 \mathrm{IU} / \mathrm{ml}$.

The thyroid gland was diffusely enlarged (4-5 times its normal size), hypoechoic and heterogeneous, and a large number of hypoechoic heterogeneous nodular lesions, $55 \times 40 \mathrm{~mm}$ in size, were observed on ultrasonography. Diffusely enlarged thyroid gland spread to the trachea, extending to the right retrosternal part and causing esophageal compression, and multiple lymphadenopathy was found on the neck on computer tomography imaging (image 1). Because of laboratory and radiological findings suspicious of anaplastic thyroid cancer, total thyroidectomy was performed. The pathology of thyroidectomy specimen was reported as Diffuse Large B Cell Lymphoma (DLBCL). Moreover, immunohistochemically, CD3 and CD5 focal positive, CD20 diffuse positive, CD23 negative, EMA and PanCK negative and Ki67 proliferation index was $90 \%$. There wasn't lymphoma involvement on the bone marrow aspiration. Cancer staging was determined as advanced stage (stage III-IV) according to the Ann-Arbor classification. The patient was considered as High Grade DLCBL and started to treat with R-CHOP. The patient died secondary to multiple-organ failure in 2 nd cycle of the chemotherapy regimen.

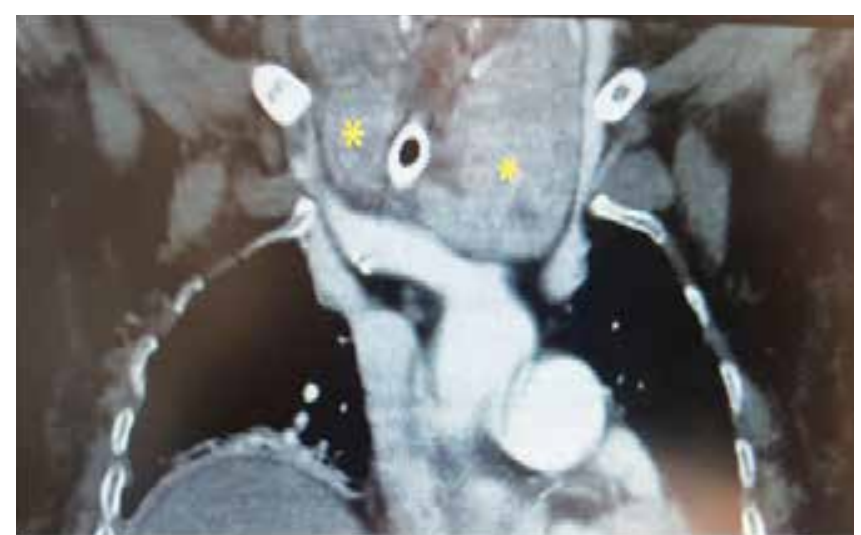

Image 1. Coronal computed tomography (CT) image showing the possible connection of the mass to the thyroid gland

\section{DISCUSSION}

DLBCL is the most common histologic subtype of nonHodgkin lymphoma (2). Patients with DLBCL typically present with a rapidly enlarging symptomatic mass, mostly nodal enlargement in the neck or abdomen (3). On the other hand, anaplastic thyroid cancer is the least common type of thyroid cancer. It is responsible for less than $2 \%$ of cases. It is a fast growing and rapidly spreading tumor, which is difficult to treat (4). We present an extremely rare case of DLBCL presenting with massive thyroid gland enlargement and resembling anaplastic thyroid cancer. In these patients, it is important to remember the causes of thyroid cancer in the differential diagnosis. Making the correct diagnosis in these aggressive cancers is very important for treatment.

Primary thyroid lymphoma affects predominantly elderly patients, the majority of them are women over 60 years of age. The condition is rare, accounting for less than $5 \%$ of all thyroid malignancies (5) and less than $2 \%$ of extranodal lymphomas (6). Thus they are seen infrequently by most pathologists and can be confused with a wide variety of entities, including benign disorders such as Hashimoto's thyroiditis at one end of the spectrum and undifferentiated carcinomas at the other (7).

DLBCL behaves in a more aggressive manner. In general, all thyroid lymphomas present with an enlarging neck mass. Indeed, a rapidly enlarging neck mass should raise suspicion for primary thyroid lymphomas and is reported in greater than $70 \%$ of cases, most commonly in those with DLBCL. Early diagnosis contributes to better management, which differs from that of other thyroid malignancies, and ensures increased rates of successful treatment without the need for radical (curative) surgical intervention. The cornerstone of current effective management is the combination of systemic chemotherapy (including biological agents) and loco-regional radiotherapy $(8,9)$.

\section{REFERENCES}

1)Cabanillas ME, McFadden DG, Durante C. Thyroid cancer. Lancet. 2016;388:2783-2795. 
2)Li S, Young KH, Medeiros LJ. Diffuse large B-cell lymphoma. Pathology. 2018;50:74-87.

3)Morton LM, Wang SS, Devesa SS, et al. Lymphoma incidence patterns by WHO subtype in the United States, 1992-2001. Blood 2006; 107:265. 4)Hui D, Proctor B, Donaldson J, et al. Prognostic implications of extranodal involvement in patients with diffuse large B-cell lymphoma treated with rituximab and cyclophosphamide, doxorubicin, vincristine, and prednisone. Leuk Lymphoma 2010; 51:1658.

5)Haugen BR, Alexander EK, Bible KC, et al. 2015 American Thyroid Association Management Guidelines for Adult Patients with Thyroid Nodules and Differentiated Thyroid Cancer: The American
Thyroid Association Guidelines Task Force on Thyroid Nodules and Differentiated Thyroid Cancer. Thyroid. 2016;26:1-133.

6)Gospodarowicz MK, Sutcliffe SB. The extranodal lymphomas. Sem. Rad. Oncol. 1995; 5; 281-300.

7)Freeman C, Berg JW, Cutler SJ. Occurrence and prognosis of extranodal lymphomas. Cancer 1972; 29: 252-260.

8)Wang JH, Chen L, Ren K. Identification of primary thyroid lymphoma with medical imaging: A case report and review of the literature. Oncol Lett. 2014;8:2505-2508.

9)Stein SA, Wartofsky L. Primary thyroid lymphoma: a clinical review. J Clin Endocrinol Metab. 2013;98:3131-8.

Ankara Eğt. Arş. Hast. Derg. (Med. J. Ankara Tr. Res. Hosp.), 2020 ; 53(3) : 232-234

Olgu sunumudur. Etik kurul onayı gerekmemektedir. Hastadan yazılı onam alınmıştır. 